\title{
PENGARUH PENGEMBANGAN SUMBER DAYA MANUSIA TERHADAP KOMPETENSI PEGAWAI PADA DINAS KEPENDUDUKAN DAN CATATAN SIPIL KABUPATEN BANGGAI
}

\author{
ERWIN NURSIN
}

\author{
Fakultas Ilmu Sosial Dan ilmu Politik Universitas Muhammadiyah Luwuk \\ erwinursin@yahoo.com
}

This research aims to determine how much the influence of human resources development towards the employees'competence in the Department of Population and Civil Registration of Banggai Regency. In collecting research data, the authors use the method of circulating a list of questionnaires and field research or observation. While the data analysis technique used is qualitative, that is by perform processing and analyzing the data obtained, and to find the influence between each variable, the authors use Simple Liner Regression to find the effect between each research variable. The population in this research is all employees of the Department of Population and Civil Registry of Banggai Regency with the total of 41 people consist of the Head of Department, the secretary, head of field, Section Head, functional elements and staff elements. In this research, samplings of this research using the technique of saturated samples with total are 41 people. From the results of the research can be concluded there is a positive influence between the process of human resource development towards the employees' competence in the Department of Population and Civil Registration of Banggai Regency of 0.075 with coefficient of determination $\mathrm{R}^{2}$ is $7.5 \%$. This means that the average competency score of $7.5 \%$ employees is determined by the human resource development process at Banggai Regency Population and Civil Registration, through the regression equation $\mathrm{Y}=$ $2.674+0.166 \mathrm{X}$, the remaining $92.5 \%$ is determined by other factors and values $\mathrm{T}$ arithmetic is equal to 1.882 while $t$ table of 2.25 , which is greater than $t$ count. This means there is no significant influence between the variables of human resource development $(\mathrm{X})$ with employee competence $(\mathrm{Y})$.

Keywords: Human Resources, Competency, Civil Servant.

PENDAHULUAN

Latar Belakang.

Perubahan-perubahan yang terjadi dari Undang-Undang Nomor 22 Tahun

1999 menjadi Undang-Undang Nomor 32 Tahun 2004 tentang Pemerintahan

Daerah dalam pelaksanaannya memerlukan kesiapan-kesiapan dari berbagai

bidang, terutama dalam menjalankan otonomi daerah yang diberikan. Adapun

faktor-faktor yang berpengaruh dalam pelaksanaan otonomi daerah adalah 
Manusia pelaksananya harus baik, Keuangan harus cukup baik, Peralatannya harus cukup dan baik serta Organisasi dan manajemennya harus baik.

Faktor pertama adalah: manusia pelaksananya harus baik karena manusia merupakan subyek dalam setiap aktivitas pemerintahan.

Pengertian baik disini adalah memiliki mentalitas atau moral yang baik dan jujur serta memiliki kemampuan yang tinggi dalam melaksanakan tugas.

Faktor kedua adalah: keuangan yang baik. Istilah keuangan di sini mengandung arti yang berhubungan dengan masalah uang antara lain berupa sumber pendapatan, jumlah uang yang cukup dan pengelolaan keuangan yang sesuai dengan tujuan dan peraturan yang berlaku.

Faktor ketiga adalah: peralatan yang cukup dan baik. Peralatan disini adalah setiap alat atau benda yang dapat digunakan untuk memperlancar kegiatan dan pekerjaan Pemerintah Daerah. Peralatan yang baik (praktis,efisien dan efektif) tentunya sangat diperlukan dalam menciptakan pemerintahan yang baik.

Faktor keempat adalah: organisasi dan manajemen yang baik. Organisasi yang dimaksud adalah organisasi dalam arti struktur yaitu susunan yang terdiri dari satuan-satuan organisasi beserta segenap pejabat, kekuasaan, tugas dan hubungannya satu sama lain dalam rangka mencapai sesuatu tujuan tertentu.

Namun asumsi yang berkembang dalam masyarakat saat ini, menunjukkan kinerja aparatur pemerintahan relatif kurang memuaskan. Apabila ditinjau dari segi kompetensi banyak pihak yang tidak mempunyai kompetensi, tidak jujur, dan tidak profesional menduduki jabatan penting dan strategis di pemerintahan. Hal ini disebabkan oleh proses pengembangan karier sumber daya 
aparatur yang ada saat ini, sehingga diperlukan program penanganan pengembangan sumber daya aparatur pemerintahan berdasarkan kompetensi.

Menilik segi urgensinya, kompetensi merupakan hal yang paling urgen dalam pengembangan kepegawaian. Setiap pegawai pemeritah daerah harus kompeten dan unggul dalam pelaksanaan tugasnya melayani masyarakat terutama sesuai dengan persyaratan kepegawaian dan jabatannya. Manajemen Sumber Daya Manusia Berbasis Kompetensi dapat didefinisikan sebagai suatu proses perencanaan, pengorganisasian, pelaksanaan, dan pengendalian aktifitas pegawai mulai dari rekrutmen sampai dengan pensiun dimana proses-proses pengambilan keputusannya didasarkan kebutuhan kompetensi jabatan dan kebutuhan kompetensi individu.

Dalam hal ini yang menjadi acuan adalah kemampuan dalam pelayanan. masyarakat merasakan bahwa banyak dari pejabat yang melaksanakan birokrasi belum dapat dikatakan kompeten sesuai dengan bidang tugas dan jabatannya. Asumsi ini memang belum dapat dijadikan acuan, namun ini menunjukkan bahwa secara fisik kompetensi dapat dilihat dari sikap dan perbuatan. Sehingga dapat juga di simpulkan asumsi masyarakat itu yang menuntut perubahan dalam manajemen kepegawaian untuk lebih mengedepankan kompetensi.

Profesionalisme, integritas, kejujuran dan kecakapan selalu menjadi syarat mutlak agar negara Indonesia dapat lepas dari krisis. Hal itu juga sesuai dengan Undang - Undang Nomor 43 tahun 1999 tentang Pokok Kepegawaian, yaitu dalam pasal 17 ayat 2 yang berbunyi: "Pengangkatan Pegawai Negeri Sipil dalam suatu jabatan dilaksanakan prinsip profesionalisme sesuai dengan kompetensi, prestasi kerja, dan jenjang pangkat yang diterapkan untuk jabatan itu 
serta syarat objektif lainnya tanpa membedakan jenis kelamin, suku, agama, ras dan golongan.

Selain alasan-alasan tersebut diatas, perubahan paradigma pemerintahan dari sentralistis ke desentralistis menyebabkan pemerintah lebih menitikberatkan kepada peningkatan pelayanan publik. Dalam mendukung pelayanan publik yang prima, maka sangat diperlukan sumber daya manusia yang kompeten dan kapabel. Ditinjau dari jumlah pegawai di Kabupaten Banggai yang relatif besar jumlahnya untuk ukuran tingkat pemerintah Kabupaten, maka untuk mendapatkan pegawai yang mempunyai standar kompetensi unggul, harus disusun mekanisme pembinaan dan pengembangan karir. Pelaksanaan pengembangan karir yang didasarkan pada kompetensi masing-masing individu harus dapat memenuhi kebutuhan tenaga profesional di bidang masing-masing. Berbagai pendekatan teori, dikaji dan di telaah untuk dapat mewujudkan suatu metode pengembangan sumber daya manusia oleh para ahli dan akademisi sehingga masukan-masukan yang bersifat membangun selalu datang dari mereka. Pemerintah Kabupaten bersama seluruh unsur Organisasi Perangkat Daerah (OPD) yang ada sebagai kunci pelaksanaan pembinaan dan pengembangan pegawai selalu merespon dengan baik masukan tersebut sehingga kebutuhan pengembangan sumber daya aparatur berdasarkan kompetensi di pandang sangat diperlukan.

\section{Rumusan Masalah.}

Dari gambaran latar belakang diatas dapat dirumuskan dalam rumusan masalah adalah seberapa besar pengaruh pengembangan sumber daya Manusia 
terhadap kompetensi pegawai pada Dinas Kependudukan dan Catatan Sipil Kabupaten Banggai.

\section{TINJAUAN PUSTAKA.}

Sumber daya manusia atau man power merupakan kemampuan yang dimiliki oleh setiap manusia berupa daya pikir dan kemampuan fisiknya dalam menjalankan tugas atau aktivitas yang dilakukan. Sumber daya manusia menjadi unsur pertama dan utama dalam setiap aktivitas yang dilakukan. Sebab walaupun memiliki peralatan dan sistem yang canggih, tidak akan berarti apa-apa tanpa didukung oleh sumber daya manusia yang berkualitas. Hal ini sesuai dengan pengertian sumber daya manusia menurut Sedarmayanti (2001:27) menyatakan bahwa: "Secara mikro, dalam arti lingkungan suatu unit kerja (departemen atau organisasi yang lain) maka sumber daya manusia adalah: tenaga kerja atau pegawai dalam suatu organisasi yang mempunyai peran penting dalam mencapai keberhasilan”. Selanjutnya Khairuddin (1992:45) mengatakan bahwa: "Sumber daya manusia dapat diartikan sebagai kemampuan manusia (baik fisik maupun pikiran) yang dimanfaatkan untuk mencapai kebutuhan-kebutuhan hidupnya”. Dalam pengertian ini terkandung upaya pengembangan aktivitas dalam pendidikan, kesehatan dan kebutuhan lainnya. Berdasarkan pengertian tersebut maka dalam konteks organisasi Pemerintah, yang dimaksud dengan sumber daya manusia adalah Pegawai Negeri Sipil (PNS) yang berfungsi sebagai abdi negara dan abdi masyarakat.

Pegawai Negeri Sipil Pemerintah yang dimaksud disini adalah Pegawai Negeri Sipil sebagaimana yang tercantum dalam Pasal 1 No.1 Undang-Undang Nomor 43 Tahun 1999 tentang perubahan Undang-Undang Nomor 8 Tahun 1974 
tentang Pokok-Pokok Kepegawaian yang menyatakan bahwa Pegawai Negeri Sipil adalah "Setiap Warga Negara Republik Indonesia yang telah memenuhi syarat yang ditentukan, diangkat oleh pejabat yang berwenang dan diserahi tugas dalam suatu jabatan negeri, atau diserahi tugas Negara lainnya, dan digaji berdasarkan peraturan perUndang-undangan yang berlaku”.

Sumber daya manusia sebagai modal utama bagi organisasi diharapkan dapat memberikan kontribusi atau manfaat yang sebesar-besarnya pada organisasi. Oleh karena itu sumber daya manusia yang ada haruslah senantiasa ditingkatkan kemampuannya melalui kegiatan pengembangan sumber daya manusia sehingga dapat melaksanakan tugas dan tujuan organisasi dengan baik.

Sumber Daya Manusia menurut Nawawi dalam Sedarmayanti (2001:26) bahwa :

a) Sumber Daya Manusia adalah manusia yang bekerja di lingkungan suatu organisasi.

b) Sumber Daya manusia adalah potensi manusiawi sebagai penggerak organisasi dalam mewujudkan eksistensinya.

c) Sumber Daya Manusia adalah potensi yang merupakan aset dan berfungsi sebagai modal di dalam organisasi yang dapat diwujudkan menjadi potensi nyata secara fisik dan non fisik.

Sumber daya manusia menurut Notoatmojo (2003:27) bahwa bagaimanapun baiknya organisasi perlengkapannya sarana dan fasilitas kerja, semuanya tidak akan mempunyai arti tanpa ada manusia yang mengatur, menggunakan dan memeliharanya. 
Thoha (2003:316) berpendapat bahwa Sumber Daya Manusia adalah Kemampuan merupakan salah satu unsur dalam kematangan berkaitan dengan pengetahuan dan keterampilan yang diperoleh dari pendidikan, latihan dan pengalaman.

Dalam konteks kualitas Sumber Daya Aparatur di era otonomi, Wasistiono (2002:266-267) mengatakan bahwa "Kemampuan profesional dan keterampilan teknis para pegawai yang termasuk kepada unsur staf dan pelaksana di lingkungan pemerintah daerah ini sangat diperlukan agar manajemen pemerintahan dalam otonomi daerah dapat berlangsung secara efektif dan efesien yang diperlukan tidak hanya jumlahnya yang cukup, tetapi juga kwalitas para pegawai yang harus diukur dengan melihat latar belakang pendidikan, keterampilan, pengalaman kerja, jenjang kepangkatan dan status kepegawaian”.

Pengembangan sumber daya manusia merupakan salah satu aspek dari manajemen sumber daya manusia. Pengembangan sumber daya manusia adalah suatu usaha yang penting dalam setiap organisasi, karena kegiatan pengembangan dapat menciptakan pegawai yang bermutu sehingga organisasi dapat lebih maju dan bekembang. Pegawai yang bermutu adalah mereka yang mempunyai kecakapan dan kemampuan untuk menyelesaikan suatu pekerjaan yang dibebankan kepadanya serta dapat memelihara dan meningkatkan kecakapan dan kemampuannya secara teratur dan pasti.

Pengembangan sumber daya manusia adalah setiap usaha atau kegiatan yang dimaksudkan untuk merubah perilaku seseorang pegawai yang meliputi pengetahuan, kecakapan dan sikap-sikap dalam usaha pembinaan pegawai. Atmodiwirio (2005:4) mengatakan bahwa "Pengembangan manusia mengacu 
kepada kemajuan pengetahuan, keterampilan, kompetensi dan peningkatan perilaku manusia dalam organisasi baik untuk kegunaan pribadinya maupun kegunaan profesional. Pengembangan manusia dalam organisasi diarahkan pada peningkatan kinerja agar organisasi mendapat keuntungan, bertambah besar efisiensi, lebih efektif dalam kompetensi dan lebih mampu menghasilkan keuntungan. Inilah komponen pengembangan sumber daya manusia. Pengembangan kinerja pegawai adalah tujuan utama pengembangan sumber daya manusia".

Pengembangan untuk seluruh pegawai adalah penting bagi organisasi untuk meningkatkan kemampuan sumber daya manusia dalam menghadapi perkembangan dan perubahan dimasa mendatang. T. Hani Handoko (2001:103) menyatakan bahwa "Ada dua tujuan utama pengembangan sumber daya karyawan. Pertama, latihan dan pengembangan dilakukan untuk menutup gap antara kecakapan dan kemampuan karyawan dengan permintaan jabatan. Kedua, program-program tersebut diharapkan dapat meningkatkan efisiensi dan efektifitas kerja karyawan dalam mencapai sasaran kerja yang telah ditetapkan”. Atmodiwirio (2005:21) menyatakan bahwa pokok-pokok strategis pengembangan sumber daya manusia :

a) Penyempurnaan sistem perencanaan pegawai (man power planning) untuk memperoleh pegawai-pegawai yang dibutuhkan oleh sistem;

b) Penyempurnaan sistem pendidikan dan pelatihan untuk meningkatkan profesionalisme, mutu dan kepemimpinan Pegawai Negeri Sipil;

c) Klasifikasi jabatan, pengelompokan pegawai menurut jenis profesinya; 
d) Penyempurnaan administrasi kepegawaian didukung sistem informasi yang terpercaya;

e) Perbaikan dalam tingkat kesejahteraan pegawai.

Berdasarkan pada strategi diatas, kebijakan operasional yang diperlukan adalah:

a) Penyempurnaan sistem perencanaan pegawai

Setiap kebutuhan pegawai harus didasarkan pada analisis kebutuhan yang terdiri dari analisis jabatan, analisis beban kerja dan perkiraan kapasitas kerja per orang per satuan waktu. Dalam kerangka ini diperlukan penyempurnaan sistem informasi pegawai untuk merencanakan kebutuhan pegawai baru dan pendidikan dan pelatihan;

b) Penyempurnaan sistem pendidikan dan pelatihan pegawai yang disesuaikan dengan kebutuhan.

Penyempurnaan meliputi pendidikan penjenjangan (stuktural dan fungsional) dan peningkatan koordinasi pelatihan teknis fungsional, sehingga setiap saat bisa dipantau tingkat profesionalisme pegawai.

c) Pengembangan karier pegawai melalui pengelompokan jabatan menurut jenis keahliannya: pengembangan jabatan fungsional serta perumusan ketentuan yang mengatur pengangkatan pegawai dalam jabatan struktural.

Penyelenggaraan administrasi diarahkan pada pelayanan pegawai yang lebih baik dalam pengarahan hak-haknya yang tepat waktu. Perlu penyederhanaan berbagai perUndang-undangan tentang kepegawaian. 
Peningkatan kesejahteaan pegawai melalui penghematan belanja pegawai yang tidak perlu. Upaya penghematan dilakukan dengan mereviu kembali kebijaksanaan Undang-Undang pegawai.

Kompetensi adalah Kemampuan kerja yang mencakup aspek Pengetahuan, ketrampilan dan sikap kerja. Menurut Spencer dalam Musanef (1991:12) kompetensi adalah "Suatu karakteristik dasar individu yang memiliki hubungan kausal atau sebab akibat dengan kriteria yang dijadikan acuan, efektif, atau berperfomansi superior di tempat kerja, atau pada situasi tertentu.Yang dimaksud dengan karakteristik dasar terdiri dari motif,bawaan,konsep diri, pengetahuan dan keahlian (skill)".Hubungan kausal yang dimaksud adalah hubungan sebab akibat antara hasil perilaku dengan karakteristik dasar tersebut. Sedangkan karakteristik acuan yang merupakan kriteria hasil perilaku bersifat relatif yang berujud prestasi kerja.

Dalam pemerintah daerah, setiap aparat mempunyai karakter dasar masing-masing.karakter ini terdiri dari yang mampu dilihat dan tidak dapat dilihat. Yang mampu dilihat adalah pengetahuan dan keahlian, sedangkan yang tidak dapat dilihat adalah motivasi, konsep diri dan sikap bawaan. Adapun mengenai definisi hal tersebut adalah:

a) Motif adalah sesuatu yang secara konsisten dipikirkan dan diinginkan oleh seseorang yang memunculkan suatu tindakan.

b) Bawaan adalah karakteristik fisik atau kebiasaan seseorang dalam merespon suatu situasi atau informasi tertentu.

c) Konsep diri adalah keyakinan, sikap, dan tata nilai seseorang yang mempengaruhi tindakan pengambilan keputusan dan perilakunya 
d) Pengetahuan adalah informasi yang dimiliki oleh seseorang pada area yang spesifik.

e) Keahlian adalah kemampuan untuk melakukan aktifitas fisik dan mental.Keahlian mental atau kognitif meliputi pemikiran analitis, serta konseptual .

Secara umum standar kompetensi dibagi dalam enam kelompok. Hal ini juga berlaku didunia pemerintahan dalam rangka pengembangan sumber daya aparaturnya agar memenuhi kriteria yang baik dan unggul. Adapun standar kompetesi tersebut menurut Spencer dalam Musanef (1991:103) antara lain:

a) Kemampuan untuk merencanakan dan mengimplementasikan yang diukur dengan semangat berprestasi (Achievement Organitation), Ketelitian terhadap kejelasan tugas (Concern for order), Inisiatif (Initiative) dan pencarian informasi (Information Seeking).dalah hal ini diharapkan aparatur pemerintahan daerah yang menjabat pada jabatan tertentu mempunyai standar superior daripada pegawai biasa. Tentu saja hal ini akan dapat dicapai melalui pengembangan dengan standar kompetensi yang jelas.

b) Kemampuan melayani yang dapat diukur dengan melalui Empati (Interpersonal Understanding), dan Orientasi pada pelanggan (Costumer Service Orientation). Aparatur pemerintah daerah diharapkan semua memenuhi standar ini sesuai dengan keinginan masyarakat selaku konsumen atau pelanggan.

c) Kemampuan memimpin dapat diukur melalui kemampuan mendorong dan mempengaruhi, kesadaran berorganisasi, dan membangun hubungan kerja. 
d) Kemampuan manajerial yang dapat diukur melalui kemampuan mengembangkan orang lain (Developing Others), Mengarahkan orang lain (Directiveness), Kemampuan memimpin kelompok (Team Leadership)

e) Kemampuan Berpikir diukur dengan kemampuan berpikir analisis dan kemampuan berpikir konsepsional, serta keahlian profesional (expertise)

f) Kemampuan bersikap dewasa yang dapat diukur dari Pengendalian diri (self Controll), Kepercayaan Diri (Self Confidence), dan Penyesuaian diri (flexibility).

\section{METODE PENELITIAN.}

Metode Penelitian yang digunakan dalam penelitian ini adalah metode survey yaitu suatu metode penelitian yang mengambil sampel dari populasi serta menggunakan kuesioner sebagai alat alat pengumpulan data yang pokok (Efendi,2001:3). Penleiti memilih data penelitian ini kedalam dua jenis data yaitu data Primer dan data sekunder. Data Primer yaitu data yang diperoleh dari informasi secara langsung. data sekunder yaitu data yang digunakan untuk memperjelas data primer yang diambil dari dokumen dokumen yang ada dilokasi penelitian.

Penelitian ini mengambil lokasi di wilayah Kerja Kabupaten Banggai tepatnya pada kantor Dinas Kependudukan dan Catatan Sipil Kabupaten Banggai dengan jumlah Populasi sebanyak 46 orang pegawai dengan metode pengambilan sampel menggunakan metode sampling jenuh.

\section{Metode analisis.}

Dalam penelitian ini penulis menggunakan teknik analisis data yang bersifat kualitatif, yaitu dengan mengadakan pengolahan dan penganalisaan data 
yang diperoleh. Data yang sudah terkumpul dibagi-bagi dan disusun kedalam kelompok-kelompok, sehingga tersusun secara sistematis dan akan memudahkan dalam penelitian.

Untuk memudahkan dalam perhitungan hasil penelitian maka penulis menggunakan skor sebagai alat bantu. Setiap jawaban dari responden ditetapkan nilai dan sekornya, yang ditentukan sebagai berikut:

Penentuan persentase $(\mathrm{X})$ dari jawaban tersebut menggunakan rumus:

$$
\Sigma \text { (frekuensi jawaban } \mathrm{x} \text { bobot) }
$$

Skor $=$

Skor Tertinggi

$\mathrm{n}$

Keterangan :

Skor tertinggi $=5 \mathrm{x}$ jumlah sampel/responden.

Skor terendah $=1 \times$ jumlah sampel/responden.

Penentuan persentase untuk memudahkan penarikan kesimpulan dengan menggunakan rumus :

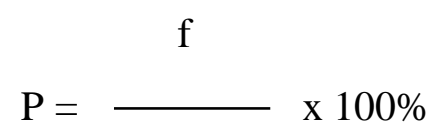

$\mathrm{n}$

Keterangan :

$\mathrm{P} \quad=$ Prosentase

$\mathrm{f}=$ = Jumlah respon yang memilih suatu jawaban

$\mathrm{n} \quad=$ Jumlah seluruh responden

$100 \%=$ Bilangan tetap 
Setiap jawaban dari responden ditetapkan persentase dan skornya dan ditarik sebuah jawaban, yang ditentukan sebagai berikut:

Penentuan Persentase dari jawaban indikator tersebut menggunakan rumus :

$\Sigma($ frekuensi jawaban $\mathrm{x}$ bobot

$$
\text { Persentase }=\quad \mathrm{X} 100 \%=
$$

Skor tertinggi $=5 \mathrm{x}$ jumlah sampel/responden

Skor terendah $=1 \times$ jumlah sampel/responden

Peneliti menggunakan kriteria minimal $20 \%$ dengan gambaran jika responden memilih semua jawaban skor 1 maka perhitungannya sebagai berikut :

Skor observasi

$$
\begin{aligned}
\text { Kriteria mimimal }= & \frac{\text { Skor kriteria }}{46 \times 1} \times 100 \% \\
= & \frac{}{46 \times 5} \times 100 \% \\
& =20 \%
\end{aligned}
$$

2. Penentuan Kriteria Penilaian Jawaban.

$$
\text { Kriteria Maksimal - Kriteria Minimal }
$$

$$
\text { Interval }=
$$

$$
100 \%-20 \%
$$

$$
\text { Interval }=\longrightarrow \quad=16 \%
$$


Apabila data diinterprestasikan dalam bentuk persentase maka penetapan klasifikasi jawaban responden adalah sebagai berikut :

1. $87 \%$ sampai $100 \%$ dikategorikan sangat baik.

2. $70 \%$ sampai $86 \%$ dikategorikan baik

3. $54 \%$ sampai $69 \%$ dikategorikan cukup baik

4. $37 \%$ sampai $53 \%$ dikategorikan kurang baik

5. $20 \%$ sampai $36 \%$ dikategorikan sangat tidak baik

Sedangkan untuk mencari pengaruh antar setiap variabel, maka penulis menggunakan Regresi Liner sederhana sebagai alat bantunya, dengan persamaan sebagai berikut :

$$
\hat{Y}=a+b X
$$

Keterangan :

$\mathrm{Y}^{\prime} \quad=$ Variabel dependen (nilai yang diprediksikan)

$\mathrm{X}=$ Variabel independen

a $=$ Konstanta (nilai $\mathrm{Y}^{\prime}$ apabila $\mathrm{X}=0$ )

$\mathrm{b}=$ Koefisien regresi (nilai peningkatan ataupun penurunan)

dimana untuk mencari a dan b digunakan rumus sebagai berikut :

$(\Sigma Y i)\left(\Sigma X i^{2}\right)-(\Sigma X i)(\Sigma X i Y i)$

$\mathbf{a}=$

$$
\mathrm{n} \Sigma \mathrm{Xi} \mathrm{i}^{2}-(\Sigma \mathrm{Xi})^{2}
$$

n $\Sigma \mathrm{Xi} Y \mathrm{i}-(\Sigma \mathrm{Xi})(\Sigma \mathrm{Yi})$

$\mathbf{b}=$

$$
n \Sigma X i^{2}-(\Sigma X i)^{2}
$$


dengan nilai r Korelasi dihitung dengan rumus :

$$
\mathbf{r}=\frac{\mathrm{n} \sum \mathrm{XiYi}-\left(\sum \mathrm{Xi}\right)\left(\sum \mathrm{Yi}\right)}{\sqrt{\left\{\mathrm{n} \sum \mathrm{Xi}^{2}-\left(\sum \mathrm{Xi}\right)^{2}\right\}\left\{\mathrm{n} \sum \mathrm{Yi}^{2}-\left(\sum \mathrm{Yi}\right)^{2}\right\}}}
$$

Sedangkan Koofesien Deteminasi dihitung dengan rumus :

$\mathrm{KD}=\mathrm{r}^{2} \times 100 \%$.

\section{PEMBAHASAN}

Untuk mengetahui pengaruh antara pengembangan sumber daya manusia dengan kopetensi pegawai, maka mengacu pada alat bantu hitung SPSS 17.00 For Windows seperti pada lampiran, dan berdasarkan tabel coefficient ${ }^{\mathrm{a}}$ maka diperoleh koefisien untuk variabel X adalah sebesar 0,166 dan Konstanta sebesar 2,674 sehingga model persamaan yang diperoleh adalah :

$$
Y=2,674+0,166 X
$$

Dimana :

$\mathrm{X}=$ Variabel Terikat (pengembangan sumber daya manusia)

$\mathrm{Y}=$ Variabel Bebas (kompetensi pegawai)

b. Uji t Atau uji Parsial

Dalam penelitian ini untuk Uji t penulis menggunakan alat bantu hitung SPSS 17.00 For Windows, dengan ketentuan bahwa jika nilai t hitung > t tabel maka hipotesa dapat diterima, dan sebaliknya jika $\mathrm{t}$ hitung $<\mathrm{t}$ tabel, maka hipotesa ditolak.

Berdasarkan lampiran penelitian, dapat diketahui derajat kebebasan $\mathrm{df}=46$ -

1 dengan signifikan $5 \%$ adalah sebesar 2,25. dan berdasarkan tabel regresi 
sederhana dan uji t dapat diketahui bahwa nilai t hitung adalah sebesar 1,882 sedangkan t tabel sebesar 2,25, yang lebih besar dari pada t hitung. Artinya tidak terdapat pengaruh yang signifikan antara variabel pengembangan sumber daya manusia (X) dengan kompetensi pegawai(Y).

Sedangkan konstanta sebesar 2,674, artinya jika pengembangan sumber daya manusia (X) nilainya 0 (nol), maka kompetensi pegawai (Y) akan mengalami penurunan sebesar $(-2,674)$. Sedangkan koefisien regresi variabel pengembangan sumber daya manusia $(X)$ sebesar $(0,166)$ mengasumsikan bahwa tiap ada kenaikan proses pengembangan sumber daya manusia (X) maka kompetensi pegawai (Y) juga akan meningkat sebesar 16,6 \% dengan anggapan konstan sebesar 2,674, serta dianggap signifikan karena angka sig 0,066. berada dibawah 0,5 atau $5 \%$.

\section{c. Koofesien Determinasi $\mathrm{R}^{2}$}

Sebagaimana telah dideskripsikan pada tabel model Summary pada lampiran penelitian ini diketahui nilai kofesien determinasi sebesar 0,273, Nilai ini dapat diinterpretasikan bahwa hubungan kedua variabel penelitian ada di kategori lemah. Melalui tabel ini juga diperoleh nilai R Square atau koefisien determinasi (KD) yang menunjukkan seberapa bagus model regresi yang dibentuk oleh interaksi variabel bebas dan variabel terikat. Nilai Koofesien Determinasi dalam penelitian ini adalah sebesar 0,075 atau $7,5 \%$ yang dapat ditafsirkan bahwa variabel bebas $\mathrm{X}$ memiliki pengaruh kontribusi sebesar 7,5\% terhadap variabel Y dan 92,5\% lainnya dipengaruhi oleh faktor-faktor lain diluar variabel X. 
Dari hasil pengolahan data statistik analisis regresi linier sederhana menggunakan alat bantu SPSS for windows 17.00 diketahui bahwa dari hasil koefisien regresi diketahui besarnya parameter standard koefisien regresi untuk variabel bebas yaitu pengembangan sumber daya manusia $(\mathrm{X})$ dengan variabel terikatnya kompetensi pegawai (Y) sebesar 0,166 Dari persamaan terlihat bahwa parameter koofisien regresi untuk variabel pebgembangan sumber daya manusia (X) adalah positif terhadap proses kompetensi pegawai (Y). dengan demikian, maka setiap terjadi kenaikan pada kegiatan pengembangan sumber daya manusia pada Dinas Kependudukan dan Catatan Sipil Kabupaten Banggai maka kompetensi pegawai akan ikut naik, begitupula sebaliknya. Adapun model persamaan regresi yang diperoleh adalah :

$Y=2,674+0,166 X$

Dimana :

$\mathrm{X}=$ Variabel Terikat (pengembangan sumber daya manusia) $\mathrm{Y}=$ Variabel Bebas (kompetensi pegawai)

Berdasarkan persamaan regresi tersebut, bisa dilihat bagaimana pengembangan sumber daya manusia $(\mathrm{X})$ terhadap kompetensi pegawai (Y) koofisien konstanta sebesar 2,674, artinya jika pengembangan sumber daya manusia (X) nilainya 0 (nol), maka proses pendaftaran tanah (Y) akan mengalami penurunan sebesar $-2,674$. Sedangkan koefisien regrasi variabel pengembangan sumber daya manusia (X) sebesar 0,166 satu satuan, maka kompetensi pegawai (Y) akan mengalami kenaikan sebesar 16,6\%. jadi semakin tinggi pengembangan sumber daya manusia maka kompetensi pegawai Dinas Kependudukan dan Catatan Sipil Kabupaten Banggai pun akan naik pula. 
Untuk melihat pengaruh variabel pengembangan sumber daya manusia (X) dengan variabel kompetensi pegawai (Y), dapat diketahui nilai R Squere sebesar 0,075, hal ini mengasumsikan bahwa variasi perubahan variabel kompetensi pegawai (Y) dipengaruhi oleh perubahan variabel pengembangan sumber daya manusia $(X)$ sebesar 7,5\%, sedangkan sisanya 92,5\% dipengaruhi oleh faktor lain diluar penelitian ini. Sedangkan untuk mengetahui signifikan tidaknya ditunjukkan perbandingan antara $t$ hitung dengan $t$ tabel, diketahui dari item uji hipotesis parsial menunjukan bahwa nilai t hitung adalah sebesar 1,882 sedangkan t tabel sebesar 2,25, yang lebih besar dari pada t hitung. Artinya tidak terdapat pengaruh yang signifikan antara variabel pengembangan sumber daya manusia (X) dengan kompetensi pegawai (Y). Hal ini berdasarkan olahan data yang ada pada dinas Dinas Kependudukan Dan Catatan Sipil Kabupaten Banggai menujukan bahwa yang sangat berpengaruh dari aspek kopetensi pegawai adalah kemampuan melayani masyarakat,kemampuan memimpin, serta kemampuan bersikap dewasa.

\section{KESIMPULAN}

Berdasarkan rumusan masalah penelitian dan pengolahan data pada babbab sebelumnya, maka kesimpulan yang dapat diambil dalam penelitian ini adalah terdapat pengaruh positif antara proses pengembangan sumber daya manusia terhadap kompetensi pegawai Dinas kependudukan dan Catatan Sipil Kabupaten Banggai sebesar 0,075. dengan koofesian determinasi $\mathrm{R}^{2}$ adalah 7,5 $\%$. Hal ini berarti nilai rata-rata kompetensi pegawai 7,5\% ditentukan oleh proses pengembangan sumber daya manuisa pada Dinas kependudukan dan Catatan Sipil Kabupaten Banggai, melalui persamaan regresi $\quad \mathrm{Y}=2,674+0,166$ 
$\mathrm{X}$, sisanya 92,5\% ditentukan oleh faktor lain dan nilai t hitung adalah sebesar 1,882 sedangkan $t$ tabel sebesar 2,25, yang lebih besar dari pada t hitung. Artinya tidak terdapat pengaruh yang signifikan antara variabel pengembangan sumber daya manusia (X) dengan kompetensi pegawai(Y).

\section{SARAN}

Berdasarkan hasil penelitian, penulis dapat memberikan saran sebagai berikut :

1. Unsur pimpinan pada Dinas kependudukan dan Catatan Sipil Kabupaten Banggai wajib meningkatkan kompetensi kerja pegawai guna pencapaian tujuan utama Pemerintah Daerah Kabupaten Banggai

2. Dalam pengembangan kompetensi pegawai harus menggunakan berbagai cara selain pengembangan sumber daya manusia karena pengaruh masing-masing cara dapat mempercepat peningkatan kompetensi pegawai.

3. Kompetensi pegawai dapat dilakukan dengan cara mengikutsertakan para pegawai dalam setiap kegiatan pendidikan dan pelatihan yang berkesesuaian dengan tugas pokok dan fungsi yang diemban oleh para pegawai

4. Perlunya peningkatan anggaran operasional guna perbaikan sumber daya pegawai yang berorientasi pada bantuan pendidikan dan bantuan kegiatan pelatihan pegawai.

5. Proses rekruitmen pegawai harus lebih diperhatikan lagi dengan menitikberatkan pada latar belakang keilmuan dan pengalaman kerja serta kompetensi lainnya yang mendukung pelaksanaan fungsi dari Dinas Kependudukan dan Catatan Sipil

\section{DAFTAR PUSTAKA}

Atmodiwirio, Soebagio, 2005, Manajemen Pelatihan, Ardadizya Jaya, Jakarta

Arikunto, Suharsimi, 1998, Prosedur Penelitian Suatu Pendekatan Praktek, Rineka Cipta, Jakarta

Handoko, Hani T , 2001, Manajemen Personalia dan Sumber Daya Manusia, BPFEYogyakarta, Yogyakarta

Hasibuan Malayu,2000, Manajemen Sumber Daya Manusia, Bumi Aksara, Jakarta 
Khairuddin, 1992, Pembangunan Masyarakat, Liberty, Yogyakarta.

Mangkunegara, Anwar Prabu, 2004, Manajemen Sumber Daya Manusia Perusahaan, PT. Remaja Rosdakarya, Bandung

Musanef, 1991, Manajemen Kepegawaian di Indonesia, CV. Haji Masagung, Jakarta

Moekijat, 1986, Manajemen Kepegawaian, Alumni, Bandung

Nazir, Mohamad, 1999, Metode Penelitian, Ghalia Indonesia, Jakarta

Notoatmojo, Soekidjo, 2003, Pengembangan Sumber Daya Manusia, PT. Rineka Cipta, Jakarta

Sedarmayanti, 2001, Sumber Daya Manusia dan Produktivitas Kerja, CV. Mandar Maju, Bandung

Sugiyono, 2002, Metodologi Penelitian Administratif, CV. Alfabeta, Bandung

Thoha,Miftah,2003, Kepemimpinan dalam Manajemen, PT. Raja Grasindo Persada, Jakarta ,1998, Perilaku Organisasi, PT. Raja Grafindo Persada, Jakarta

Wasistiono, Sadu, 2002, Menajemen Sumber Daya Aparatur Pemerintah Daerah, Fokus Media, Bandung

Widjaya, A.W, 1995, Administrasi Kepegawaian Suatu Pengantar, PT. Raja Grafindo Persada, Jakarta. 
